\title{
HUBUNGAN PENGETAHUAN IBU TENTANG MAKANAN BERGIZI DENGAN PEMBERIAN MAKANAN PENDAMPING ASI PADA BAYI UMUR 6-12 BULAN DI WILAYAH KERJA PUSKESMAS KARANG PULE
}

\author{
Rizkia amilia1*, Nurul Qomariah Rista Andaruni*
}

*Kebidanan, Universitas Muhammadiyah Mataram, ichoamilia@gmail.com

\begin{tabular}{l} 
INFO ARTIKEL \\
\hline Riwayat Artikel: \\
Diterima: 09-02-17 \\
Disetujui: 14-07-17 \\
\end{tabular}

Kata Kunci:

Pengetahuan Ibu Makanan Bergizi

Pemberian MPASI

Bayi umur 6-12 bulan

\section{A. LATAR BELAKANG}

Setiap keluarga pasti menginginkan untuk mempunyai bayi yang sehat dan cerdas supaya di kemudian hari bayi tersebut tumbuh menjadi generasi penerus yang berguna bagi orang tua, bangsa dan negara. Salah satu upaya untuk mewujudkan hal itu adalah dengan memberikan makanan yang terbaik untuk bayi sejak dini (Tuti, 2010).

\begin{abstract}
Abstrak: Pengetahuan tentang makanan bergizi sangat penting bagi ibu karena akan meningkatkan status gizi bayi. Tujuan untuk mengetahui hubungan antara tingkat pengetahuan tentang makanan bergizi dengan pemberian makanan pendamping ASI pada bayi umur 6-12 bulan di Puskesmas Karang Pule tahun 2015. Penelitian ini menggunakan metode observasional analitik dengan pendekatan cross sectional. Populasi dalam penelitian ini adalah ibu yang mempunyai bayi usia 6- -12 bulan yang memberikan makanan pendamping ASI. Teknik pengambilan sampel yang digunakan adalah teknik accidental sampling. Pengumpulan data dilakukan dengan wawancara menggunakan alat bantu kuesioner. Analisa data dilakukan menggunakan uji chi square. Hasil penelitian menunjukkan bahwa sebagian besar ibu berusia 20-35 tahun sebanyak 23 orang (76,7\%), berpendidikan menengah sebanyak 15 orang (50,0\%), bekerja sebanyak 20 orang $(70,0 \%)$, berpengetahuan baik sebanyak 22 orang (73,3\%) dan pemberian MP-ASI sebanyak 25 orang $(83,3 \%)$. Berdasarkan hasil uji chi square diperoleh nilai probabilitas (signifikansi) sebesar $(0,000)<$ $(0,05)$. Berdasarkan hasil penelitian di atas dapat disimpulkan bahwa terdapat hubungan yang signifikan antara tingkat pengetahuan tentang makanan bergizi dengan pemberian makanan pendamping ASI pada bayi umur 6-12 bulan.
\end{abstract}

ABSTRAK

\begin{abstract}
Knowledge about nutritious food is very important for the mother because it will improve the nutritional status of infants. The purpose to find out the relationship between the level of knowledge about nutritious foods with complementary feeding of breast milk in infants aged 6-12 months in year 2015 Pule Coral health centers. This research use analytic observational method with cross sectional approach. The population in this research is the mother who has a baby age 6-12 months which gives food companion exclusive breasfeeding. Sampling technique used was accidental sampling techniques. Data collection is done with the interview questionnaire using the tools. Data analysis was performed using chi square test. The results showed that the majority of mothers aged 20-35 years as many as 23 people (76.7\%), secondary educated as much as 15 people (50.0\%), work as many as 20 people (70.0\%), knowledgeable well as many as 22 people (73.3\%) Complementary feeding and as many as 25 people (83.3\%). Based on the test results of the chi square probability value obtained (significance) of $(0.000)<(0.05)$. Based on the above research results it can be concluded that there is a significant relationship between the level of knowledge about nutritious foods with complementary feeding of breast milk in infants aged 6-12 months.
\end{abstract}

Air susu ibu (ASI) merupakan makanan terbaik untuk bayi, karena ASI mengandung hampir semua zat gizi dengan komposisi sesuai kebutuhan bayi. Walaupun ASI merupakan makanan terbaik bagi bayi dengan bertambahnya umur, bayi yang sedang tumbuh memerlukan energi dan zat-zat gizi yang melebihi jumlah yang didapat dari ASI. Pada umumnya setelah bayi berumur 4-6 bulan ASI sudah tidak dapat 
memenuhi kebutuhan gizi bayi, dengan demikian bayi memerlukan energi tambahan (Paath, 2007).

Makanan pendamping ASI harus diberikan pada umur yang tepat sesuai kebutuhan dan daya cerna bayi. Adanya kebiasaan masyarakat untuk memberikan nasi, pisang pada umur beberapa hari ada bahayanya, karena saluran pencernaan pada bayi belum sempurna. Makanan pendamping ASI sebaiknya diberikan pada umur 6 bulan karena sistem pencernaannya sudah relatif sempurna (Soraya, 2008). MPASI harus mulai diberikan ketika bayi tidak lagi mendapat cukup energi dan nutrien dari AS1 raja. Untuk kebanyakan bayi, makanan pendamping ASI mulai diberikan pasa usia 6 bulan ke atas.

Makanan Pendamping ASI (MPASI) merupakan makanan lain yang selain ASI. Makanan ini dapat berupa makan yang disiapkan secara khusus atau makanan keluarga yang dimodifikasi. Pada umur o-6 bulan, bayi tidak membutuhkan makanan atau minuman selain ASI. Artinya bayi hanya memperoleh susu ibu tanpa tambahan cairan lain, balk susu formula, made, air teh. Bayi juga tidak diberi makanan padat lain seperti pisang dan nasi lumat, bubur, susu, biskuit, nasi tim dan lain-lain (Juwono, 2008).

Survey yang dilakukan oleh UNICEF pada tahun 2005, melaporkan bahwa anak balita penderita gizi kurang di Indonesia pada tahun 2005/2006 baik menjadi 2,3 juta dibanding sebelumnya pada tahun 2004/2005 yang berjumlah 1,8 juta. Sedangkan, menurut Departemen Kesehatan dalam Rancangan Aksi Pencegahan dan Penanggulangan Gizi Buruk 2005-2009, prevalensi gizi buruk dan gizi kurang di Indonesia adalah 27,5\% (Dekes RI, 2013)

Hasil pemantauan status gizi Depkes RI tahun 2012 dengan menggunakan indeks berat badan menurut umur $(\mathrm{BB} / \mathrm{U})$, berat badan menurut tinggi badan $(\mathrm{BB} / \mathrm{TB})$ dan tinggi badan menurut umur $(\mathrm{TB} / \mathrm{U})$, diketahui status gizi buruk pada balita di Provinsi NTB tahun 2012 sebesar 3,53\%. Kondisi ini lebih baik jika dibandingkan dengan prevalensi gizi buruk tahun 2011 sebesar $4,57 \%$. Presentase gizi buruk terbesar ada di Kabupaten Bima dan Kota Bima. Namun prevalensi gizi kurang di Provinsi NTB tahun 2012 tidak jauh berbeda dengan prevalensi gizi kurang tahun 2011. Tahun 2012 prevalensi gizi kurang sebanyak 14,11\% dan tahun 2011 sebanyak $14,87 \%$. Balita gizi kurang terbanyak di Kabupaten Lombok Utara (Depkes RI, 2012).

Berdasarkan uraian di atas peneliti tertarik untuk mengadakan penelitian tentang "Hubungan Pengetahuan Ibu tentang Makanan Bergizi dengan Pemberian Makanan Pendamping ASI pada Bayi Umur 6-12 Bulan di wilayah kerja Puskesmas Karang Pule Tahun 2015."

\section{B. METODE PENELITIAN}

Populasi dalam penelitian ini adalah ibu yang mempunyai bayi usia 6-12 bulan yang memberikan makanan pendamping ASI. Dilaksanakan pada Agustus 2016 di wilayah kerja puskesmas Karang Pule karena di puskesmas karena memiliki data bayi berumu 6-12 bulan.

Penelitian ini merupakan penelitian observasional analitik yaitu dimana peneliti hanya melakukan pengamatan saja atau melakukan pengukuran-pengukuran saja dan tidak melakukan intervensi. Rancangan penelitian menggunakan cross sectional. Teknik pengambilan sampel yang digunakan adalah teknik accidental sampling. Pengumpulan data dilakukan dengan wawancara menggunakan alat bantu kuesioner.

Teknik analisa data yang digunakan dalam penelitian ini menggunakan perhitungan statistik sederhana yaitu presentase atau proporsi (Notoatmodjo, 2012). Data dianalisis dengan menggunakan uji ChiSquare dan pengolahan data ini dilakukan dengan bantuan komputer melalui program SPSS 16.00.

\section{HASIL DAN PEMBAHASAN}

Hubungan pengetahuan tentang makanan bergizi dengan pemberian makanan pendamping ASI pada bayi umur 6-12 bulan ditunjukkan oleh tabel 4.7 berikut.

TABEL 1

Hubungan Tingkat Pengetahuan dengan Pemberian MP-ASI di Wilayah Kerja Puskesmas Karang

\begin{tabular}{|c|c|c|c|c|c|c|}
\hline \multirow{3}{*}{$\begin{array}{c}\text { Tingkat } \\
\text { Pengetahuan }\end{array}$} & \multicolumn{4}{|c|}{ Pemberian MP ASI } & \multirow{2}{*}{\multicolumn{2}{|c|}{ Total }} \\
\hline & \multicolumn{2}{|c|}{ Baik } & \multicolumn{2}{|c|}{ Buruk } & & \\
\hline & $\mathrm{N}$ & $\%$ & $\mathrm{~N}$ & $\%$ & $\mathrm{~N}$ & $\%$ \\
\hline Baik & 22 & 40 & 22 & 40 & 44 & 80 \\
\hline Cukup & 3 & 5 & 8 & 15 & 11 & 20 \\
\hline Kurang & $\mathrm{o}$ & $\mathrm{o}$ & 0 & 0 & $\mathrm{o}$ & 0 \\
\hline Total & 25 & 45 & 30 & 55 & 55 & 100 \\
\hline \multicolumn{7}{|c|}{ P-value: 0,000} \\
\hline
\end{tabular}

Dengan demikian, hasil penelitian ini menunjukkan bahwa ada hubungan yang signifikan antara pengetahuan tentang makanan bergizi dengan pemberian makanan pendamping ASI pada bayi umur 612 bulan di wilayah kerja Puskesmas Karang Pule tahun 2016. Karena pada penelitian ini diperoleh hasil bahwa sebagian besar responden mempunyai pengetahuan baik dan dengan kategori pemberian makanan pendamping ASI yang baik. Dengan demikian dapat disimpulkan bahwa semakin tinggi pengetahuan seseorang tentang makanan bergizi, maka akan semakin baik dalam pemberian makanan pendamping ASI. Hal ini dikarenakan pengetahuan tentang makanan bergizi yang benar akan membentuk kepercayaan dan akan memberikan dasar bagi pengembangan prilaku dan tindakan yang benar dan tepat dalam pemberian makanan pendamping ASI. Pada usia ini MP-ASI sangat penting untuk menambah energi dan zat gizi yang diperlukan (Anonim, 2007). 


\section{SIMPULAN DAN SARAN}

Simpulan penelitian ini adalah Berdasarkan tingkat pengetahuan tentang makanan bergizi, sebagian besar responden berpengetahuan baik yaitu sebanyak 22 orang (73,3\%). ebagian besar perilaku responden dalam pemberian MP-ASI dengan kategori baik yaitu sebanyak 25 orang $(83,3 \%)$.

Berdasarkan hasil uji Chi Square pada tingkat kepercayaan $\alpha=0,05$; diperoleh hasil bahwa nilai probabilitas (signifikansi) sebesar $(0,000)<(0,05)$ yang artinya terdapat hubungan yang signifikan antara pengetahuan tentang makanan bergizi dengan pemberian makanan pendamping ASI pada bayi umur 612 bulan di Puskesmas Karang Pule tahun 2015.

Saran penelitian ini diharapkan kepada orangtua untuk memperhatikan status gizi bayi dengan memberikan makanan pendamping ASI yang sehat dan bergizi seimbang yang berguna bagi pertumbuhan dan perkembangan anak, sehingga tujuan kesehatan balita dapat tercapai.

\section{DAFTAR RUJUKAN}

[1] Juwono, L. (2003). Pemberian Makanan Pendamping ASI. Buku Kedokteran EGC. Jakarta.

[2] Notoatmodjo, S.(2012). Metodologi Penelitian Kesehatan. Jakarta : Rineka Cipta.

[3] Paath, EA, dkk. (2007). Gizi dalam Kesehatan Reproduksi. Jakarta : EGC.

[4] Saryono. (2010). Ilmu Kebidanan. Jakarta : Yayasan Bina Pustaka

[5] Soraya.(2008). Resiko Pemberian MP-ASI Terlalu Dini,(online)(http:/lwww.bayikita.wordpress.com,diaks es 7 November 2016)

[6] Undang-Undang Sistem Pendidikan Nasional No. 20 Tahun 2005.

[7] Winkjosastro, H. (2009). Ilmu Kebidanan. Jakarta: Yayasan Bina Pustaka. 